Krystyna Dzwonkowska-Godula

Zakład Socjologii Płci i Ruchów Społecznych

Wydział Ekonomiczno-Socjologiczny

Uniwersytet Łódzki

Jakub Ryszard Stempień

Zakład Socjologii

Katedra Nauk Humanistycznych

Uniwersytet Medyczny w Łodzi

\title{
OD RELACJI BADACZ - RESPONDENT DO RELACJI PSYCHOTERAPEUTA - PACJENT? WYBRANE PROBLEMY ETYCZNE WYWIADÓW BIOGRAFICZNYCH
}

\section{Wprowadzenie - kwestie etyczne w badaniach socjologicznych}

Problem stosunku łączącego socjologa i respondenta - uczestnika wywiadu socjologicznego pozostaje przedmiotem refleksji metodologicznej i etycznej od długiego czasu. Specyfika tego stosunku w jego każdorazowych urzeczywistnieniach wpływa bowiem na jakość i wartość pozyskiwanych danych. Socjologowie uświadamiają sobie zarazem, że ich relacje z badanymi nie są relacjami naturalnymi i same z siebie nie mają charakteru neutralnego; nie są ani zwyczajne, ani „przezroczyste”. Konieczne jest wobec tego przeprowadzanie określonych zabiegów - zalecanych w podręcznikach ankieterskich oraz akademickich podręcznikach badań społecznych - aby sytuację wywiadu socjologicznego (zarówno standaryzowanego, jak również jakościowego) znormalizować i zneutralizować w ten sposób, aby wywiad przypominał zwyczajną rozmowę. Zabiegi te powinny prowadzić nie tylko do uzyskiwania wiarygodnych informacji, lecz powinny także 
pozytywnie wpływać na komfort respondenta. Możliwie dobre samopoczucie uczestnika badań socjologicznych $\mathrm{w}$ ich trakcie oraz po ich zakończeniu pozostaje bowiem etycznym zobowiązaniem, przed którym staje badacz. Etycy są zgodni, że udział w badaniu nie powinien oznaczać dla respondenta psychicznych lub fizycznych przykrości czy uciążliwości.

Earl Babbie w popularnym podręczniku badań społecznych (2004: 515-520) wskazuje na następujące standardy etyczne, które obowiązują badaczy: zasada anonimowości/poufności, zasada dobrowolnego uczestnictwa, zasada niekrzywdzenia uczestników oraz, wynikająca z dwóch ostatnich reguł, zasada świadomej zgody. Ta ostatnia norma oznacza, że respondenci wyrażają zgodę na swój udział w badaniu ze świadomością możliwych zagrożeń oraz z pełną wiedzą na temat tego, na czym polegać będzie badanie, czego mogą spodziewać się ze strony badacza oraz czego badacz będzie oczekiwać od nich ${ }^{1}$.

Podobne zalecenia są formułowane w Kodeksie etyki socjologa, uchwalonym przez Walne Zgromadzenie Delegatów Polskiego Towarzystwa Socjologicznego 25 III 2012 r. Zgodnie z § 7, ,,socjologowie mają obowiązek zapewnić, by prowadzone badania nie miały negatywnego wpływu na stan fizyczny, społeczny i psychiczny ich uczestników”. Natomiast § 9 stanowi, że „udział w badaniach socjologicznych powinien opierać się na dobrowolnej i świadomej zgodzie badanych. Socjolog ma obowiązek wyjaśnienia, w słowach zrozumiałych dla badanych, czego dotyczy badanie, kto je prowadzi oraz w jaki sposób zostaną upowszechnione oraz wykorzystane jego wyniki”. Warto tu przypomnieć również treść § 13 Kodeksu..., wedle którego „na socjologach ciąży obowiązek ustalenia, jakie skutki może nieść ze sobą wykonywana przez nich praca. O ile jest to możliwe, powinni starać się przewidzieć i zabezpieczyć uczestników badania przed konsekwencjami dla nich szkodliwymi. Z powyższego obowiązku nie zwalnia socjologów zgoda udzielona przez uczestników badania”. W § 14 podkreśla się z kolei, że ,socjologowie powinni sprawdzić, czy badanie nie będzie dolegliwe dla badanych i postarać się, jeżeli jest to konieczne, znaleźć sposoby na zminimalizowanie lub złagodzenie dolegliwości, jakich mogą w związku z tym doznawać badani. Należy pamiętać, że podjęte w ramach badań decyzje mogą mieć wpływ na funkcjonowanie jednostek w grupie, nawet jeżeli poszczególnych badanych chronią zasady poufności i anonimowości”.

\footnotetext{
${ }^{1}$ E. Babbie zdaje sobie sprawę, że nie w każdej sytuacji możliwe jest postępowanie badacza zgodne z tymi zasadami. W sytuacjach wyjątkowych - gdy inne sposoby realizacji badania prowadziłyby do jałowych rezultatów - dopuszczalne jest prowadzenie badań niejawnych (bez dobrowolnego, świadomego udziału) lub oszukiwanie badanych (często sprzeczne z zasadą ich niekrzywdzenia oraz niezgodne z wymogiem świadomej zgody) (Babbie 2004: 520-521). Badacz jest zobowiązany do ograniczania w takich przypadkach negatywnych skutków, z jakimi wiąże się dla respondentów udział w badaniu.
} 
Podobne zalecenia zostały sformułowane w Międzynarodowym Kodeksie Badań Rynku i Badań Społecznych ICC/ESOMAR. Warto tu jedynie przypomnieć, że do zbioru fundamentalnych zasad Kodeksu... zaliczono m.in. dwie następujące: a) „Współpraca respondentów jest dobrowolna i ma opierać się na adekwatnej oraz niemylącej informacji o ogólnym celu i naturze badania, podanych przy ubieganiu się o ich zgodę, i wszystkie te oświadczenia mają być honorowane”; b) „Badacze rynku mają respektować prawa respondentów jako osób prywatnych, bez narażania ich na szkody lub niepożądane bezpośrednie następstwa udziału w badaniu rynku".

Powyższe etyczne standardy prowadzenia badań socjologicznych (oraz szerzej: badań społecznych) są dobrze znane i powszechnie uznawane. Odnoszą się do wszystkich reaktywnych technik badawczych. W tej właśnie perspektywie omówione zostaną wybrane aspekty realizacji wywiadów biograficznych w ich narracyjnej formule. Wskazane zostaną pewne problematyczne kwestie etyczne (wiążące się z wykonywaniem tych wywiadów), często pomijane lub marginalizowane przez badaczy. W ocenie autorów niniejszego artykułu, wywiady biograficzne (w niektórych przypadkach) mogą w sposób istotny naruszać zasadę niekrzywdzenia badanych oraz zasadę świadomej zgody. Wywiady biograficzne mogą stanowić źródło poważnych obciążeń psychicznych dla obydwu partnerów interakcji i mogą stawiać respondenta, jak też badacza (sic!) w nieoczekiwanych oraz trudnych dla nich rolach. Prezentowane w tekście tezy opierają się przede wszystkim na realiach polskiej socjologii, jednak obserwowane problemy etyczne mają niewątpliwie charakter uniwersalny.

Wywiady biograficzne mają charakter opowieści o życiu respondenta (ang. life history) - całym jego przebiegu bądź wybranym fragmencie, konkretnym obszarze aktywności, np. działalności zawodowej czy życiu rodzinnym. Narracja może odnosić się tylko do jakiegoś kluczowego momentu przebiegu życia, związanego $\mathrm{z}$ ważnymi wydarzeniami historycznymi, zmianą ról i pozycji społecznej itd. (Włodarek, Ziółkowski 1990: 5). Celem badania jest nie tyle odtworzenie faktów z życia jednostki, co poznanie „subiektywnej interpretacji własnego życia dokonanej przez samego respondenta, będącej często [...] idealizacją rzeczywistości, środkiem rozwiązywania życiowych problemów, próbą racjonalizacji własnej biografii. Interesująca wydaje się zwłaszcza dynamika tej subiektywnej interpretacji, zachodzące (wraz z upływem czasu i wpływem nowych znaczeń), odmienne ich tłumaczenie sobie i partnerom, inne postrzeganie zależności warunkujących zmienne postrzeganie i odczuwanie odpowiedzialności, zasług, winy czy wstydu" (ibidem: 6). To autentyczność owej relacji o życiu stanowi wartość dla badacza. Istotne jest zatem nie tylko o czym, ale jak opowiada respondent, jakie wydarzenia czy doświadczenia eksponuje, co próbuje przemilczeć w swojej opowieści, jak wyjaśnia określone zjawiska, jakie emocje towarzyszą przywoływanym wspomnieniom itp. 


\section{Akulturacja relacji socjolog - respondent. Problem świadomej zgody}

Zasygnalizowano wyżej, że realizacja wywiadów biograficznych może wiązać się z nieprzestrzeganiem dwóch etycznych zobowiązań badacza: świadomej zgody oraz niekrzywdzenia badanych. Dla analizy problemu świadomej zgody respondenta na udział $w$ badaniu socjologicznym istotne znaczenie ma kwestia akulturacji badań społecznych, a więc ich kulturowej rozpoznawalności, czytelności, oswojenia. Jak pisze Katarzyna Grzeszkiewicz-Radulska, akulturacja funkcjonuje na poziomie jednostkowym oraz makrospołecznym. W pierwszym przypadku, poszczególni ankietowani postrzegają sytuację wywiadu jako potoczną i określoną; wiedzą, jakimi wzorcami zachowań należy się tu posługiwać (Grzeszkiewicz-Radulska 2001). Akulturacja w makrospołecznym wymiarze oznacza natomiast występowanie społecznego wysokiego poziomu akceptacji badań oraz ich zinstytucjonalizowania i zintegrowania z kulturą (ibidem: 51; Przybyłowska 1996). Jeśli w danym społeczeństwie istnieje wysoki poziom akulturacji badań socjologicznych (lub szerzej: społecznych), to nawet w przypadku zastosowania przez badacza szczątkowych formuł aranżacyjnych można mówić o świadomej zgodzie respondentów na udział w wywiadzie. Uczestnicy wiedzą bowiem, czym są badania i na czym będzie polegać ich udział w tym przedsięwzięciu. Natura badań, o której jest mowa w przytoczonym fragmencie Kodeksu ESOMAR, pozostaje dla nich czytelna i rozbudowane wyjaśnienia ze strony badacza nie wydają się niezbędne.

W przypadku społeczeństwa polskiego akulturacja badań socjologicznych postępowała powoli i była przez długi czas uwarunkowana specyfiką państwa realnego socjalizmu. Można też mówić o istotnym zapóźnieniu w porównaniu z krajami zachodnimi, gdzie prowadzenie sondaży, a także badań rynkowych rozpoczęto wcześniej. W PRL-u badania były słabo rozpoznawalne, respondenci często nie rozumieli, czego się od nich oczekuje, w jaki sposób mają udzielać odpowiedzi i dlaczego są im w ogóle zadawane jakieś pytania; nierzadko bali się udziału w tych przedsięwzięciach, identyfikując je z inwigilacyjnymi działaniami władz. Często stosowali określone - niekorzystne z punktu widzenia badacza strategie działania w sytuacji wywiadu, która była dla nich nowa i stresująca (m.in. udzielanie wyłącznie odpowiedzi zgodnych $\mathrm{z}$ oficjalnym programem rządzącej partii) (Staszyńska 1989: 40-49, 79 i n.; Lutyńska 1984: 51-54; Lutyński 1990: 91-92; Przybyłowska 1996; Kubiak, Przybyłowska, Rostocki 2001: 161-163; Kubiak 2007: 64-65; Sułek 1990: 59-74; 2011: 278). 
Obecnie można powiedzieć, że w Polsce badania socjologiczne (i szerzej: społeczne) są już dobrze rozpoznawalne. Należy jednak podkreślić, że społeczne skojarzenia są tu znacznie zawężone. Zasadne wydaje się przyjęcie, że ogół badań społecznych jest postrzegany przez pryzmat najbardziej popularnych badań sondażowych (w tym zwłaszcza sondaży przedwyborczych) oraz coraz powszechniejszych badań rynkowych. Warto przypomnieć następujące stwierdzenie Antoniego Sułka: „sondaże są najbardziej znanym rodzajem badań społecznych, prowadzonych przy użyciu metod naukowych, mają więc swój wkład w uformowanie społecznego wyobrażenia, czym jest metoda naukowa zastosowana do społeczeństwa. Wkład ten jest na tyle duży, że w świadomości wielu ludzi badania sondażowe są tożsame z badaniami społecznymi, zresztą ze szkodą dla badań prowadzonych innymi metodami” (2011: 345; zob. też Kubiak 2007). Natomiast zgodnie z wynikami badania Polskiego Towarzystwa Badaczy Rynku i Opinii, w 2011 r. 45 czołowych agencji badawczych w Polsce przebadało (w badaniach rynkowych lub sondażach polityczno-społecznych) za pomocą techniki wywiadu telefonicznego ze wspomaganiem komputerowym (tzw. CATI) aż 2,8 mln respondentów. Oznacza to, że w badaniu CATI uczestniczył w 2011 r. - średnio - co dziesiąty dorosły Polak.

Konstatacje A. Sułka oraz wyniki badania PTBRiO pozwalają na wysunięcie istotnej tezy, zgodnie z którą akulturacja badań społecznych nie obejmuje wywiadów biograficznych, w tym zwłaszcza w ich narracyjnej formule. Role badacza i respondenta kształtują się bowiem w tych wywiadach odmiennie w porównaniu z ,typowymi” badaniami społecznymi, które dotyczą kwestii względnie neutralnych (np. opinie na temat produktów i problemów społecznych), nie zaś doświadczeń jak najbardziej osobistych. Pytania w wywiadach kwestionariuszowych są na ogół zamknięte, a zawsze - bardzo konkretne. Od respondenta oczekuje się wyboru jednej lub kilku odpowiedzi z zaproponowanej listy lub co najwyżej sformułowania krótkiej swobodnej wypowiedzi, w przypadku nielicznych pytań otwartych. W narracyjnych wywiadach biograficznych sytuacja przedstawia się inaczej i - o ile nie zostałaby bardzo dokładnie i szczegółowo przedstawiona, zapowiedziana $\mathrm{w}$ fazie aranżacji wywiadu - będzie ona najpewniej dla respondenta zaskakująca. Tymczasem należy podkreślić, że w przypadku narracyjnych wywiadów biograficznych badany dokładnie poznaje swoją rolę dopiero wtedy, kiedy wyrazi już zgodę na udział w całym przedsięwzięciu. Może to oznaczać zaprzeczenie reguły świadomej zgody, istotne bowiem informacje o naturze badania są przekazywane już po jego rozpoczęciu. 


\section{Charakterystyka metodologiczna wywiadów biograficznych}

Wywiady biograficzne są wywiadami swobodnymi, choć mogą być również częściowo ustrukturyzowane (Bednarz-Łuczewska, Łuczewski 2012: 97). Z reguły jednak utożsamia się je z wywiadami narracyjnymi, w których opowieść badanego o własnym życiu nie jest sumą odpowiedzi na stawiane pytania, lecz spontaniczną narracją, niezakłóconą przez interwencje badacza (Kaźmierska 1996b: 35). Ze względu na specyfikę prowadzenia tego rodzaju wywiadu oraz wiążące się z nią problemy etyczne, konieczna jest tu bliższa charakterystyka tej techniki.

Badanie z wykorzystaniem wywiadu narracyjnego składa się z kilku faz (Kaźmierska 1996b: 36; 2004b: 74). W fazie rozpoczęcia wywiadu, mającej charakter zwykłej rozmowy, badacz ma zdobyć zaufanie narratora, stworzyć „atmosferę sprzyjającą opowiadaniu”, „klimat sympatii i relaksu” (ibidem). Następna faza - stymulacji do wywiadu - służy wyjaśnieniu rozmówcy, na czym polega jego zadanie w badaniu. Dowiaduje się on wówczas, że przedmiotem zainteresowania są jego biograficzne, osobiste doświadczenia, relacja z przebiegu zdarzeń w jego życiu. Ponieważ, jak wskazano wyżej, respondenci „oswojeni” są przede wszystkim z wywiadami kwestionariuszowymi (w których udzielają odpowiedzi głównie na pytania zamknięte), w tej fazie badany poznaje nowe dla niego zasady wywiadu narracyjnego. Uświadamia mu się nie tylko, że badanie to polega na opowiadaniu przez niego historii, bez ,pomocniczych” pytań ze strony badacza, ale także, że ma on opowiadać o swoich losach, nie traktując siebie jako reprezentanta jakiejś kategorii społecznej, której opinie miałby prezentować, z czym mamy do czynienia w badaniach sondażowych (Kaźmierska 1996b: 36; 2004b: 75; Rokuszewska-Pawełek 2002: 53).

Następnie przechodzi się do zasadniczej części wywiadu - fazy narracji w której narrator przedstawia swoją biograficzną opowieść, bez interwencji ze strony badacza. Chodzi o uzyskanie spontanicznej, improwizowanej historii. Narracja może trwać nawet kilka godzin. Zgodnie z metodologicznymi wytycznymi, badacz ma jedynie podtrzymywać interakcję, zapewniając badanego, za pomocą pozawerbalnych znaków, że uważnie go słucha i jest zainteresowany jego opowieścią. Nie może ani ,pomagać” rozmówcy, gdy ten przerywa narrację, ani okazywać zniecierpliwienia, gdy pauzy w opowiadaniu przedłużają się. Nie powinien też reagować na emocje okazywane przez opowiadającego. Dopiero w fazie pytań, gdy narrator definitywnie zakończy swoją opowieść, badacz może prosić o wyjaśnienie nieścisłości, niezrozumiałych treści, czy braku konsekwencji w opowiadaniu, ,doopowiedzenie" niedokończonych wątków, uzupełnienie luk w narracji itd. Zadaje także badanemu ,pytania teoretyczne”, by poznać jego opinie, oceny, motywy, uczucia, komentarze istotne $\mathrm{z}$ punktu widzenia problematyki badania (Kaźmierska 1996b: 37-38; 2004b: 76; Rokuszewska-Pawełek 2002: 56-57). 
Ze względu na trudność i nienaturalność prowadzenia (oraz słuchania) długiej biograficznej narracji, dotyczącej często traumatycznych przeżyć, faza zakończenia wywiadu służy „normalizacji” sytuacji, co ma polegać na zwykłej, „luźnej” rozmowie z badanym (Kaźmierska 1996b: 38; 2004b: 77). Jak zauważa Kaja Kaźmierska: „z punktu widzenia zawartego w idei wywiadu narracyjnego jego moralnego przesłania, jest to faza bardzo ważna. Kończąc spotkanie z osobą, która poświęciła swój czas i obdarzyła badacza zaufaniem, winien on z kolei poświęcić swój czas traktując narratora jako partnera w interakcji, a nie jedynie »maszynkę do opowiadania«" (Kaźmierska 1996b: 38; 2004b: 77).

Narracyjne wywiady biograficzne wykorzystuje się m.in. w badaniach poświęconych doświadczeniom wojennym. W niniejszym opracowaniu odwołujemy się do badań zrealizowanych przez łódzkich socjologów (Czyżewski, Piotrowski, Rokuszewska-Pawełek 1998; Kaźmierska 1999; Rokuszewska-Pawełek 2002; Kaźmierska 2008), badań Barbary Engelking (2001) oraz Małgorzaty Melchior (2004). Narratorami były w nich m.in. osoby, które przeżyły wojnę i okupację $w$ centralnej Polsce (głównie Łódź i okolice), osoby z „,kresowymi doświadczeniami wojennymi” oraz „ocaleni z Zagłady”2.

\section{Wywiad biograficzny - perspektywa badanego}

Technika wywiadu biograficznego jest trudna zarówno dla badanego, jak i dla badacza. W opinii autorów niniejszego artykułu problemem może być: 1) nienaturalność sytuacji wywiadu, 2) utrata kontroli nad własną narracją, 3) trudność w tworzeniu narracji, 4) konieczność odnoszenia się do traumatycznych doświadczeń z własnej biografii i ryzyko wtórnej traumatyzacji.

Jak podkreśla K. Kaźmierska, ,należy pamiętać, że decyzja o podzieleniu się opowieścią o swoim życiu wiąże się z podjęciem intelektualnego, emocjonalnego, a także czysto fizycznego wysiłku, na który zarówno badacz, jak i narrator muszą być przygotowani” (2004b: 75). Można postawić pytanie, czy postulowane przygotowanie jest rzeczywiście możliwe. Wydaje się, że uczestnicy nie są w stanie do końca przewidzieć własnych reakcji na narrację dotyczącą trudnych momentów z biografii. W związku z tym trudno jest im wypracować jakiś schemat „właściwego" postępowania. Dotyczy to przede wszystkim narratora, dla którego sytuacja, w jakiej ma on opowiedzieć historię swojego życia, jest prawdopodobnie nowa i niezwykła, choć w opracowaniach poświęconych badaniom

\footnotetext{
${ }^{2}$ Uwadze Czytelnika należy też z pewnością polecić wyniki interesujących badań Anny Wylęgały, dotyczących społecznej pamięci powojennych przesiedleń (na przykładzie Polski i Ukrainy) (2013).
} 
biograficznym wskazuje się na „naturalność” tworzenia narracji o sobie. Jak stwierdzają Paulina Bednarz-Łuczewska i Michał Łuczewski, ,ludzie nie zawsze brali udział w sondażach, nie zawsze wypełniali testy i uczestniczyli w eksperymentach, ale zawsze opowiadali historie. W badaniach biograficznych nie narzucamy nikomu jakiejś sztucznej, nienaturalnej formy, lecz jedynie inicjujemy narracje, które w innych kontekstach jednostka tak czy inaczej tworzy" (Bednarz-Łuczewska, Łuczewski 2012: 100). Alicja Rokuszewska-Pawełek zauważa z kolei, że „każdy czuje się ekspertem, jeśli chodzi o własne życie i opowiadanie o przeżytych doświadczeniach jest formą komunikacji znaną każdemu uczestnikowi życia codziennego" (2002: 52). Badaczka podkreśla, że sytuacja narracyjna, w której jedna osoba opowiada, a druga słucha jej relacji, jest równie naturalną formą potocznej komunikacji jak konwersacja (ibidem: 65).

Wobec powyższych założeń, można jednak wysunąć pewne krytyczne komentarze. Przede wszystkim, jak zauważa Marek Prawda, „w codziennych kontaktach partnerzy rzeczywiście sobie coś opowiadają, ale także wymieniają poglądy, zajmują stanowisko wobec wysłuchanej relacji. Nie do pomyślenia jest „naturalna” sytuacja, w której partner się nie odzywa i nie wpływa jakoś na przebieg i treść komunikacji” (1989: 95). Tu na sztuczność sytuacji wpływa także fakt nagrywania wywiadu na dyktafon, z czym badanych trzeba ,oswoić” w fazie rozpoczęcia wywiadu. Należy również podkreślić fakt, że gdy ludzie w codziennych sytuacjach opowiadają o wydarzeniach ze swojego życia, to wynika to z reguły z ich potrzeby ,wygadania się”, to oni zatem są inicjatorami ,skonstruowania narracji o sobie", wybierają moment oraz odbiorcę, dając sobie tym samym prawo przerwania jej $\mathrm{w}$ dowolnym momencie, prowadzenia jej $\mathrm{w}$ określony sposób itd. Można założyć, że w sytuacji wywiadu, poproszeni o odtworzenie historii własnej biografii (czy jej fragmentu), czują się zobowiązani do poprowadzenia narracji do końca oraz uczynienia jej zrozumiałą (co wymaga np. uszczegółowienia). Zgodnie z regułą zaangażowania i konsekwencji, gdy badani zgodzili się na przeprowadzenie z nimi wywiadu narracyjnego (prawdopodobnie nie w pełni wiedząc, na co się zgadzają), nie będzie im „wypadało” wycofać się z wykonania zadania, do którego się zobowiązali (Cialdini 2003).

Co więcej, można powiedzieć, że prezentując opowieść o swoim życiu w wywiadzie narracyjnym, narrator w pewien sposób traci nad nią kontrolę, nie panuje nad nią, co stanowi wartość dla badacza, uzyskującego improwizowaną opowieść, nieprzygotowaną wcześniej i niezakłóconą a więc „w specyficznym sensie - autentyczną" (Prawda 1989: 95, 96). Jak podkreślają P. Bednarz-Łuczewska i M. Łuczewski, ,dla badacza społecznego nie bez znaczenia jest fakt, że długie wypowiedzi badanych w wywiadach zmniejszają ryzyko narzucania im schematów i hipotez wyjściowych. [...] Narracja już po kilku minutach uniezależnia się od określających ją warunków początkowych (pytania 
badacza) i zaczyna płynąć własnym torem. Ponadto taką wypowiedź jest jednocześnie trudniej badanemu kontrolować, nie może on nieustannie jej monitorować i udzielać odpowiedzi obliczonych wyłącznie na wywarcie pewnego efektu. Rola autoprezentacji ulega tu znacznemu osłabieniu" (Bednarz-Łuczewska, Łuczewski 2012: 101, 102). W rezultacie narrator może mieć na koniec poczucie, że powiedział więcej niż chciał, że musiał wspomnieć o wątkach swojej biografii, które wolałby przemilczeć, że źle zaprezentował się w oczach badacza.

W wywiadach narracyjnych wykorzystuje się fakt, że improwizowane opowiadanie historii własnego życia wymusza na jednostce przestrzeganie określonych zasad komunikowania się (np. trzymanie się porządku wydarzeń, dygresje poświęcone pojawiającym się $\mathrm{w}$ opowieści osobom czy zdarzeniom mającym wpływ na przebieg biografii, przedstawianie „tła” wydarzeń itp.). Wskazuje się na trzy przymusy, jakim podlega narrator: przymus kondensacji (,zagęszczanie” opowieści - mówienie o tym, co podstawowe i znaczące $\mathrm{z}$ punktu widzenia biografii badanego); przymus wchodzenia w szczegóły oraz przymus zamykania form (kontynuowanie zaczętych tematów, dopowiedzenie ich do końca) (Kallmeyer, Schütze 1977: 188 za: Rokuszewska-Pawełek 2002: 54-55). Dzieje się tak, tym bardziej że odbiorcą autobiograficznej opowieści jest badacz niewiedzący nic o opowiadającym, któremu trzeba „wszystko” wyjaśnić. Jak ujmuje to M. Prawda, ,jeżeli zapraszam kogoś do odwiedzenia świata moich przeżyć i doświadczeń, to przystaję na reguły, które tym odwiedzinom nadają sens” (1989: 89). W badaniu jednak tym, który „zaprasza” - otwiera interakcyjną sytuację wywiadu i rozdziela role pomiędzy jej uczestników, jest słuchacz, a nie „nadawca” opowieści i to jego oczekiwania mają być spełnione. „Jego wyraźne życzenie zapoznania się z tą historią jest także milczącą odmową podejmowania kolejek, co oznacza, iż jedynym sposobem redukowania bariery obcości pozostaje opowiadanie badanego" (Prawda 1989: 96).

Ponadto, gdy w codziennym życiu ludzie opowiadają o sobie, nie zawsze wystarczy im bycie wysłuchanym, oczekują wyrazów wsparcia, rady, pocieszenia itp. Tego badacz nie jest $\mathrm{w}$ stanie im zapewnić, bo zgodnie $\mathrm{z}$ założeniami metodologicznymi ma on być „zdystansowany”, unikać „zakłócających” tok opowiadania „interwencji”, ograniczać się do niewerbalnych znaków podtrzymywania interakcji (Kaźmierska 1996b: 36-37).

Kolejnym problemem dla badanego proszonego o udzielenie biograficznego wywiadu jest trudność tworzenia narracji o sobie. Oczekuje się od niego spójnej opowieści o własnym życiu, powrotu do doświadczeń i przeżyć, których „być może dotąd nie miał okazji »sobie opowiedzieć«" (Prawda 1989: 96). Problem w tworzeniu opowieści o sobie wynikać może z tego, że nie wszystkie doświadczenia biograficzne są ,narracyjne”, a więc podatne na opowiadanie 
(Kaźmierska 1996a: 86). Dotyczy to przede wszystkim wspomnień związanych z traumatycznymi przeżyciami. Jak zauważa K. Kaźmierska, ,powrót pamięcią do tragicznych chwil często ożywia cierpienie. Niejednokrotnie narrator nie chce więc zwracać się ku przeszłości, aby uniknąć ponownej pracy biograficznej nad doświadczeniem cierpienia, które dodatkowo jest niejako z samej swej natury nieprzekazywalne. Zdarza się zatem, iż jednostki mają trudności z opowiadaniem o tej części swojej biografii. Jeśli decydują się mimo wszystko na opowiedzenie o przeżytym cierpieniu, to niejednokrotnie $\mathrm{w}$ narracji pojawiają się luki dotyczące najbardziej traumatycznych doświadczeń lub ich opis jest bardzo skrótowy i schematyczny" (ibidem). Wspomina o tym także A. Rokuszewska-Pawełek, odwołując się nie tylko do własnych obserwacji, ale także refleksji innych badaczy (G. Rosenthal, B. Engelking) (Rokuszewska-Pawełek 2002: 69). Wskazuje ona, że w badaniach dotyczących traumatycznych doświadczeń wojennych (ale także innych doświadczeń trajektoryjnych) pojawia się „,zasem częściowa, niekiedy zaś niemal całkowita, niemożność mówienia na temat własnych doświadczeń. [...] Zarówno traumatyczny, ale także w większości pasywny charakter tych doświadczeń związanych z koniecznością znoszenia cierpienia powoduje, iż $\mathrm{z}$ trudem dają się one przetwarzać $\mathrm{w}$ historie, sprowadzając się zazwyczaj do skrótowych, skondensowanych formuł" (ibidem).

Narratorzy w badaniach B. Engelking przyznawali, że do tej pory unikali myślenia o strasznych wydarzeniach i bolesnych przeżyciach z przeszłości:

Ja bronię się przed wspomnieniami, ponieważ potem nawiedzają mnie koszmarne sny (Ewa); Myśmy, proszę pani, przez kilkadziesiąt lat nie otwierały ust, po co to wszystko opowiadać [...] Ja nawet po tylu latach nie lubię wspominać, bo jak przeczytam coś albo obejrzę w telewizji, to mam okropne sny (Barbara) (Engelking 2001: 280-281).

Badacz, prosząc o opowieść biograficzną, zmusza więc niejako badanych do przeżywania na nowo wypieranych doświadczeń, co może wiązać się z ryzykiem wtórnej traumatyzacji. Jak zauważa A. Rokuszewska-Pawełek, „narrator, rekonstruując przebieg wydarzeń, w które był uwikłany, równolegle odtwarza związane z nimi przeżycia" (Rokuszewska-Pawełek 2002: 55). Przypomnijmy, że w przypadku narracji wojennych dotyczy to doświadczeń śmierci bliskich, masowego zniszczenia, zagrożenia życia, lęku przed śmiercią, poczucia bezsilności i bezradności, ale także wstydu wynikającego z bierności i niemożności działania, poczucia winy wobec zmarłych (,,dlaczego ja żyję, skoro tylu innych zginęło?") czy wyrzutów sumienia w związku z ukrywaniem przez lata własnej tożsamości (Żydzi, którzy przeżyli wojnę na ,aryjskich papierach”). 
Barbara Engelking, analizując przyczyny, dla których badani odmawiali opowiadania o swoich przeżyciach z czasów wojny, wskazywała, że przeszłość stanowiła dla nich ogromny ciężar, sama pamięć o niej była przyczyną cierpienia: „Często więc próbują oni uciec od wspomnień, zapomnieć, wyprzeć, ignorować lub negować własne przeżycia" (Engelking 2001: 271). Ponadto, obawiali się oni niezrozumienia ze strony otoczenia (doświadczenia wojenne jako ,niemożliwe do przekazania innym") oraz oceny ich zachowań i postaw z okresu wojny przez ludzi, którzy nie znali tamtych warunków (ibidem).

Należy podkreślić, że tym, którzy zdecydują się opowiedzieć o swoim życiu, badacz nie daje możliwości ukrycia, zatajenia lub przemilczenia pewnych faktów czy doświadczeń. Badacze zauważają bowiem, kiedy w narracjach pojawiają się tzw. przesłonięcia - częściowe lub całkowite pominięcia czy też luki w relacji doświadczeń biograficznych (teraźniejsze i ówczesne, zamierzone i niezamierzone) (Kaźmierska 2004b: 82; Rokuszewska-Pawełek 2002: 55). Jak stwierdza A. Rokuszewska-Pawełek, ,narrator może podejmować próby kamuflażu, tuszowania czy omijania pewnych wątków, co również odzwierciedla się w narracji poprzez pojawienie się luk, zwłokę, nagłą zmianę perspektywy opowiadania, czy też zmianę schematu komunikacyjnego (np. gwałtowne przejście od narracji do argumentacji)" (Rokuszewska-Pawełek 2002: 55). Jednak w fazie pytań badacz dąży do wyjaśnienia wszelkich nieścisłości, braku konsekwencji w opowiadaniu, niedokończonych wątków, niezrozumiałych treści, pyta narratora o intencje, motywy, uczucia, a także o opinie. Jeżeli badany celowo próbował ominąć jakiś wątek w swojej biografii, nie chciał o kimś czy o czymś mówić, tu zostaje „wywołany do tablicy". Może się to wiązać z uczuciem dyskomfortu, zażenowania czy wstydu (,przyłapano mnie” na kłamstwie).

\section{Wywiad biograficzny - perspektywa badacza}

Jak wspominano wyżej, udział w wywiadzie narracyjnym może być trudny nie tylko dla respondentów, lecz także dla samych socjologów. Trudności, które mogą sprawiać badaczom, to: 1) sztuczna sytuacja wywiadu - wymóg ,niereagowania" w trakcie opowieści narratora; 2) wymóg dystansu i bezstronności wobec reakcji emocjonalnych badanego; 3) wymóg sztywnej realizacji schematu wywiadu; 4) konieczność „normalizacji” sytuacji w fazie zakończenia wywiadu.

Można powiedzieć, że wymóg „niereagowania”, milczenia w trakcie opowieści narratora i ograniczanie się do pozawerbalnych znaków podtrzymywania interakcji jest sprzeczny $\mathrm{z}$ obowiązującymi normami kulturowymi, kanonami prowadzenia konwersacji (być może jest to nawet wbrew naturze człowieka). 
W zwykłej rozmowie włączamy się w to, co mówi rozmówca, na bieżąco dopytujemy, dopowiadamy, ,pomagamy”, gdy rozmówca zamilknie i szuka właściwych słów. Jak zauważa K. Kaźmierska, ,wyrobiony przez tradycyjne techniki badawcze nawyk pytania, oraz potoczny schemat komunikacyjny niejako wykluczający milczenie jednego z partnerów interakcji, trudne są do wyeliminowania. [...] Niełatwa jest też do opanowania podyktowana »naturalnym « impulsem chęć natychmiastowego uściślenia informacji przez od razu zadane pytanie" (Kaźmierska 1996b: 36-37; 2004b: 76). Prowadzący wywiad musi się zatem nauczyć opanowywać te „naturalne” odruchy interakcyjne i komunikacyjne.

Szczególnie trudne jest powstrzymanie się od reakcji i pozostawanie zdystansowanym, gdy opowieść o swoim życiu wywołuje u badanego silne emocje. Tym bardziej, że prowadzący badanie może odczuwać - odruchowe, naturalne, ,ludzkie” - poczucie powinności zareagowania (okazania zrozumienia, współczucia) czy wręcz potrzebę udzielenia wsparcia, która nie może zostać zaspokojona. Barbara Engelking pisze wprost, że wymóg obojętności w takich sytuacjach pozostaje w sprzeczności z zasadami ogólnoludzkiej etyki: „Wiele osób wspominając własne cierpienia, przeżywało je na nowo; nieetyczne byłoby tworzenie w takich sytuacjach dystansu, pozostawienie opowiadającego samego $\mathrm{z}$ odnowionymi wspomnieniami przeszłości. Słuchacz w obliczu cudzego cierpienia musi choćby próbować w nim współuczestniczyć, musi stanowić dla swojego Rozmówcy oparcie, tworzyć klimat zaufania i zrozumienia" (2001: 12).

A zatem badacz zmaga się z dylematem, czy konsekwentnie trzymać się reguł prowadzenia wywiadu, czy po ludzku zareagować, ze szkodą(?) dla prowadzonej narracji i uzyskanego materiału: „Etyka badacza i pokora wobec ogromu cierpień drugiego człowieka stają tu w sprzeczności z dyrektywą bezstronności badacza" (ibidem: 19). Tym bardziej, że autorzy badań dotyczących traumatycznych doświadczeń, jak w przypadku narracji wojennych, mają świadomość, że rekonstrukcja przebiegu własnego życia „w tych strasznych czasach” wiąże się dla narratorów z powrotem do dramatycznych wydarzeń i towarzyszących im przeżyć. Znacząca jest tu wypowiedź B. Engelking, prowadzącej wywiady z Żydami, którzy przeżyli Holocaust (autorka planowała początkowo rozmawianie nie z nimi, lecz z ich dziećmi): „Myślę, że jednym z motywów mojej chęci rozmawiania najpierw z dziećmi ocalałych był także lęk przed poruszaniem bezpośrednio tak trudnego i bolesnego tematu. Miałam wiele oporów natury etycznej: czy wolno dla zaspokojenia własnej potrzeby zrozumienia nękać ludzi tak ciężko przez życie doświadczonych? Czy można zadawać im pytania, które zmuszają ich do ponownego przypominania sobie i przeżywania cierpienia?" (ibidem: 15). 
Jak wskazują autorzy badań, problemem jest zachowanie dystansu nie tylko w samej sytuacji wywiadu, ale także nieprzeżywanie opowieści badanych już po zakończeniu badania. Trudno pozostać obojętnym, niezaangażowanym, bezstronnym wobec historii dotyczącej traumatycznych doświadczeniach, wywołującej u opowiadającego silne emocje. W następujący sposób pisze o tym m.in. B. Engelking: „emocje opowiadających, często bolesne, cierpienie wynikające z ponownego, towarzyszącego opowiadaniu, przeżywania dramatycznych wydarzeń, niejednokrotnie udzielały się także mnie. [...] Zaczęłam zauważać u siebie objawy identyfikacji z badanymi. W okresie zbierania wywiadów, zaczęły mnie dręczyć sny i koszmary wojenne. Doświadczałam w nich, często w symbolicznej formie, niektórych dramatycznych przeżyć moich rozmówców" (ibidem: 11, 19). Dodatkowym obciążeniem może być fakt, że narrator nierzadko traktuje prowadzącego wywiad jako jedynego powiernika swojej historii, wyznaje mu, że jest on pierwszą osobą, której opowiada o danym fragmencie swojego życia, o swoich przeżyciach, motywacjach itd. (Kaźmierska 2004a: 183).

Bycie „dobrym słuchaczem” okazuje się być problematyczne dla badacza w sytuacji, gdy narrator prezentuje poglądy czy postawy, niezgodne $\mathrm{z}$ jego światopoglądem (Kaźmierska 2004a; 2004b). Wspominała o tym K. Kaźmierska: „W mojej pracy badawczej zajmuję się problemami tożsamości indywidualnej i zbiorowej, pamięcią biograficzną i społeczną. Stąd niejednokrotnie w wywiadach pojawiają się obrazy innych, stereotypy, uprzedzenia. Przeprowadzając wywiady, kilkakrotnie miałam wrażenie, że jestem »wdzięcznym « słuchaczem dla wyrażanych przez narratorów poglądów, w tym właśnie silnych niekiedy uprzedzeń, a tym samym niejako je podzielam. Były to wywiady bardzo ciekawe i wartościowe poznawczo, jednak ich przeprowadzenie wiązało się z dysonansem poznawczym" (2004b: 93). Autorka przyznała, że nie podejmowała polemiki z rozmówcami po zakończonym wywiadzie. Jej zdaniem, trudno wskazać „lepsze” rozwiązanie: czy pozostawić poglądy badanego bez komentarza, czy też jednak przedstawić mu swoje stanowisko. W pierwszym przypadku, prowadzący wywiad rozstanie się z narratorem, mając świadomość, że jest niewłaściwie odbierany (np. jako osoba równie jak badany uprzedzona wobec określonej kategorii ludzi), że jego „prawdziwe Ja” nie odpowiada wrażeniu, jakie odniósł badany. W drugim przypadku, badacz pozostanie wierny sobie i swoim poglądom, odcinając się wyraźnie od prezentowanych przez narratora opinii, może jednak go urazić, z czym też będzie źle się czuł: „Wszak przyszedł wysłuchać opowieści o doświadczeniach biograficznych, której autor poświęcił swój czas, podjął emocjonalny, intelektualny i fizyczny wysiłek narracji” (ibidem).

Jak przyznają sami badacze, w przypadku badań wiążących się z silnymi emocjami rozmówców, trudno jest trzymać się reguł prowadzenia wywiadu. Wspominano już, że zmagają się oni z dylematem, czy przerwać wywiad np. w sytuacji, gdy narrator płacze, milknie ze względu na traumatyczne wspomnienia, czy 
reagować i udzielać mu wsparcia. Łamana musi być niekiedy nie tylko reguła braku interwencji ze strony badacza. Czasem nie udaje się przejść do fazy pytań i nie można dopytać narratora o niedopowiedziane wątki, niekonsekwencje w opowieści itp. „Stykaliśmy się z sytuacjami interakcyjnie trudnymi, kiedy teoretycznie istniała możliwość postawienia danego pytania, biorąc jednak pod uwagę stan emocjonalny narratora, lub ujawnione w trakcie wywiadu cechy jego tożsamości, unikaliśmy stawiania niektórych pytań" (Kaźmierska 1996a: 38). Gabriele Rosenthal, prowadząc wywiady z ocalałymi z Zagłady, dzieliła je na kilka krótszych spotkań (oczekiwali tego sami badani, nie będąc w stanie opowiedzieć historii swojego życia w ciągu jednego kilkugodzinnego spotkania) (Rosenthal 2003: 921). W sytuacji, gdy dalsza rozmowa była zbyt trudna dla badanego ze względu na obciążenie emocjonalne, przechodziła do fazy „normalizacji” sytuacji, odkładając kontynuację badania na inny dzień.

Problemem może być wreszcie owo „znormalizowanie” sytuacji w fazie zakończenia wywiadu. Realizacja badania wymaga emocjonalnego, psychicznego i fizycznego wysiłku nie tylko ze strony narratora, ale i prowadzącego wywiad. Badacz uważnie wysłuchuje opowieści rozmówcy, (częstoją współprzeżywając), następnie ma zadać mu szereg pytań (i tych uzupełniających, „dopowiadających” narrację i tych „teoretycznych”), a na koniec zadbać o przywrócenie narratora do „stanu normalności”. W opisie schematu przeprowadzenia wywiadu narracyjnego mówi się o „Zwykłej rozmowie” z badanym. Czy to wystarczy, by zapobiec jego wtórnej traumatyzacji? W analizowanych tekstach zawierających wskazówki dotyczące realizacji wywiadów biograficznych nie wspomina się, kto i jak mógłby pomóc samemu badaczowi poradzić sobie $\mathrm{z}$ emocjami wywołanymi przez zaprezentowaną mu opowieść. Pojawia się tu problem specyficznej relacji między badaczem i badanym $\mathrm{w}$ wywiadzie narracyjnym, przypominającej w pewnej mierze relację łączącą psychoterapeutę i pacjenta.

\section{Relacja socjolog - badany w wywiadach biograficznych: ,terapeutyczne" aspekty wywiadu biograficznego}

Analogia między sytuacją biograficznego wywiadu narracyjnego a sesją terapeutyczną jest łatwo zauważalna. Udzielanie pomocy psychologicznej w ramach różnych nurtów terapeutycznych polega często na pracy z pacjentem w oparciu o tworzone przez niego autobiograficzne opowieści (Tokarska 2001: 223). Wyodrębnia się nawet „terapię narracyjną”, mającą na celu „uzyskanie konkretnych zmian $\mathrm{w}$ zachowaniu pacjenta/klienta [...], ale $\mathrm{w}$ ścisłym powiązaniu z wnikaniem w jego sposób doświadczania siebie i świata, w tym wypadku jako bohatera i autora historii własnego życia" (ibidem: 228). 
Agnieszka Golczyńska-Grondas i Marek Grondas wskazują na następujące podobieństwa między psychoterapią a prowadzeniem wywiadu narracyjnego (2013). Po pierwsze, podobna jest sama sytuacja interakcyjna - spotkanie dwóch osób, z których jedna tworzy narrację o sobie (swoim życiu), a druga jest jej odbiorcą. Po drugie, od psychoterapeuty i prowadzącego wywiad oczekuje się tych samych umiejętności interpersonalnych, takich jak np. umiejętności słuchania, wzbudzania zaufania czy zdolności komunikacyjnych. Po trzecie, schemat realizacji badania w oparciu o wywiad narracyjny przypomina do pewnego stopnia sposób prowadzenia psychoterapii. Na tym jednak - w opinii autorów niniejszego artykułu - podobieństwa się kończą, a różnice są znaczące.

Przede wszystkim inny jest cel konstruowania narracji przez jednego z uczestników interakcji, a zatem i jego oczekiwania. W przypadku psychoterapii oczekuje on, że opowieść o jego życiu, w tym także o traumatycznych doświadczeniach, pomoże mu; spodziewa się on korzystnych dla siebie rezultatów. Nawet jeśli nie jest w stanie przewidzieć swoich reakcji w związku z koniecznością powrotu do wydarzeń i przeżyć z przeszłości, to ma prawo zakładać, że partner interakcyjny udzieli mu odpowiedniego wsparcia. Psychoterapeuta jest bowiem przygotowany do podjęcia psychologicznej interwencji i na tym też polega jego rola.

Ponadto, w sytuacji wywiadu narracyjnego, biograficzna opowieść narratora ma przysłużyć się komuś innemu - stanowi przedmiot badania, materiał do socjologicznej analizy. Badany wraca do przeszłości (mimo że do tej pory mógł tego unikać, o czym wspominały narratorki w badaniu B. Engelking), podejmuje wysiłek emocjonalny, psychiczny i fizyczny nie dla siebie samego, lecz na prośbę i w interesie badacza.

Badacze niekiedy podejmują się roli terapeuty, gdy wymaga tego, ich zdaniem, sytuacja. Dotyczy to $\mathrm{z}$ reguły socjologów, będących jednocześnie psychologami (jak np. B. Engelking czy G. Rosenthal). Dla B. Engelking, prowadzącej wywiady z Żydami, którzy przeżyli Holocaust, interwencja terapeutyczna w niektórych rozmowach była czymś naturalnym i koniecznym: „Doświadczenie Holocaustu, tak trudne i bolesne do opowiadania, wymaga uważnego, empatycznego słuchacza, którego życzliwość, chęć zrozumienia i pomocy powinny ułatwić narratorowi uporanie się z własnymi emocjami. Dlatego moje rozmowy [...] czasem - w miarę potrzeby - przybierały charakter wywiadu klinicznego, terapeutycznego" (Engelking 2001: 12). Można jednak mieć wątpliwości, czy wejście badacza $\mathrm{w}$ rolę terapeuty $\mathrm{w}$ trakcie wywiadu nie jest, mimo jego najlepszych intencji, nadużyciem, czy nie oznacza zerwania swoistego kontraktu zawartego $\mathrm{w}$ momencie, gdy narrator zgodził się na udział $\mathrm{w}$ badaniu socjologicznym i poznał jego reguły (to miał być „tylko” wywiad) (Golczyńska-Grondas, Grondas 2013: 38). 
Jeśli nawet dopuścić możliwość quasi-terapeutycznych działań ze strony prowadzącego wywiad (np. już w fazie zakończenia badania, mającej polegać na „normalizacji” sytuacji), powstaje pytanie o jego kompetencje w tym zakresie. Autorzy badań dotyczących traumatycznych doświadczeń biograficznych podkreślają, że są świadomi trudności oraz obciążenia psychicznego i emocjonalnego, jakie wiążą się z budowaniem narracji. Postulują, żeby prowadzący wywiad był na nie „przygotowany”, nie precyzując jednak, na czym owo przygotowanie miałoby polegać: „W sytuacjach tak złożonych jak relacja na temat Holocaustu badacz musi liczyć się z podjętym przez siebie, ale przede wszystkim przez narratora wyzwaniem. W przypadkach gdy przewiduje się, że narrator może mieć trudności $\mathrm{z}$ powrotem do traumatycznych wspomnień, badacz powinien być przygotowany do konfrontacji z taką sytuacją" (Kaźmierska 2004b: 77). W opracowaniach poświęconych badaniom biograficznym $\mathrm{z}$ wykorzystaniem techniki wywiadu narracyjnego rzadko można spotkać komentarze i refleksje badaczy dotyczące trudnych sytuacji w wywiadzie i sposobu radzenia sobie z nimi. Są to z reguły bardzo ogólnikowe uwagi, nie odnoszące się do konkretnych przypadków.

Brak odpowiednich, czy posiadanie niewystarczających kompetencji sprawia, że skutki quasi-terapeutycznego działania badacza są, także dla niego samego, nieprzewidywalne. W przeciwieństwie do profesjonalnego psychoterapeuty jego kontakt $\mathrm{z}$ badanym jest na ogół jednorazowy, nie monitoruje zatem jego psychicznego i emocjonalnego stanu. Ponadto, jego „terapeutyczna” działalność nie podlega żadnej kontroli, podczas gdy psychoterapeuta ma możliwość przeanalizowania swojej pracy, w tym popełnionych błędów, z superwizorem.

Wskazując na istotne różnice między sytuacją wywiadu narracyjnego a psychoterapią, autorzy niniejszego artykułu nie negują możliwych terapeutycznych funkcji wywiadu narracyjnego, o których piszą badacze. Potwierdzają to psychologowie, wskazując, że „konstruowanie osobistych narracji, niezależnie od tego, że stanowi przedmiot humanistycznie zorientowanych badań psychologicznych, ma także dla samego narratora trudną do przecenienia wartość poznawczą i terapeutyczną" (Straś-Romanowska 2010: 24). Podkreśla się tu, że tworzenie opowieści (o całym swoim życiu, jego fragmencie czy też o własnej osobie autonarracja) odgrywa niezwykle ważną rolę m.in. w procesach samopoznania i samorozumienia, kształtowania się tożsamości człowieka, lepszego rozumienia innych i nawiązywania relacji z nimi (ibidem). Ponadto, ,proces narracji daje opowiadającemu możliwość odreagowania doświadczeń trudnych, przepracowania biografii, czasem przeżycia oczyszczenia - katharsis" (Kaźmierska 2004b: 77). Należy jednak pamiętać, że ewentualne oddziaływanie terapeutyczne jest niezamierzone, nieprofesjonalne i stanowi niejako „skutek uboczny” badania. 
Jak podkreśla G. Rosenthal, prowadzenie wywiadu narracyjnego jest zawsze formą psychologicznej interwencji (Rosenthal 2003: 915). Nawet jeśli socjolog jest przekonany o jego terapeutycznej funkcji i korzyściach, jakie przynosi badanym konstruowanie narracji o swoim życiu, warto za Urszulą Tokarską postawić następujące pytanie natury etycznej: „czy w ogóle można (wolno) budzić na siłę samoświadomość biograficzną i egzystencjalną jednostki, która »nie zgłasza się do nas sama po pomoc«" (2010: 310).

\section{Krytyka założeń metody}

Powyżej scharakteryzowano specyfikę realizacji wywiadów biograficznych w ich narracyjnej formule. Zasygnalizowane zostały pewne założenia, przyjmowane explicite lub implicite przez autorów, wykorzystujących tę technikę badawczą. Wskazano także na określone problemy etyczne, które mogą wiązać się z prowadzeniem narracyjnych wywiadów biograficznych. Problemy te można uznawać za wyzwanie wobec przywołanych zasad, obowiązujących badaczy społecznych. Właściwe wydaje się zrekapitulowanie najważniejszych konstatacji i podjęcie krytycznej analizy założeń, leżących u podstaw realizacji wywiadów biograficznych. Wskazać bowiem można na pięć podstawowych, istotnych metodologicznie i etycznie założeń analizowanej metody:

- założenie o świadomej zgodzie respondenta na udział w badaniu;

- założenie o naturalności, „łatwości” sytuacji narracyjnej;

- założenie o zdolności każdego człowieka do tworzenia i prezentacji narracji o sobie;

- założenie o skuteczności debriefingu, „,normalizacji”;

- założenie o psychoterapeutycznych kompetencjach socjologa oraz psychoterapeutycznych walorach samych wywiadów biograficznych.

Należy podkreślić, że - w świetle zebranych informacji - wszystkie te założenia są wątpliwe. Co więcej - albo nawet co najistotniejsze - nie są one poddawane żadnej weryfikacji. Można więc je uznać za swoistą obudowę metody, przekonującą o jej etycznej (a także metodologicznej) prawomocności nie tylko odbiorców badań, lecz także samych ich autorów.

Jak wskazano na początku, w przypadku badań mogących wiązać się z negatywnymi skutkami dla ich uczestników, kluczowe znaczenie ma wymóg świadomej zgody. Jest to wymóg wyrażenia gotowości do udziału w przedsięwzięciu socjologicznym z pełną wiedzą na jego temat $\mathrm{i}$ własnej w nim roli. Tymczasem przedstawione dane dotyczące dynamiki procesu akulturacji badań 
socjologicznych w Polsce wskazują, że zgadzając się na udział w wywiadzie biograficznym, respondent spodziewa się prawdopodobnie, iż będzie występować w znanej i społecznie „oswojonej” roli uczestnika badań sondażowych lub rynkowych. Będzie więc oczekiwać czegoś innego od tego, co faktycznie stanie się jego udziałem. Tym bardziej, że metodologiczne wytyczne dotyczące wywiadów biograficznych zalecają dokładne przedstawienie ich uczestnikom zadań i ról dopiero po rozpoczęciu wywiadu (w tzw. fazie stymulacji do wywiadu). Podsumowując, wiele wskazuje na to, że przyszli uczestnicy wywiadów biograficznych nie są w pełni świadomi (odpowiednio poinformowani) odnośnie do natury przedsięwzięcia, w którym zgadzają się uczestniczyć. Prawomocność założenia o świadomej zgodzie wydaje się zatem wątpliwa.

Wiele pisze się o nienaturalności sytuacji wywiadu kwestionariuszowego (Neyman-Mascarou 1985: 82-85). Wskazuje się, iż nie przypomina on - mimo deklaracji - zwykłej rozmowy, gdyż m.in. temat został narzucony przez jednego z uczestników i tylko jemu przypisany jest przywilej zadawania pytań (a dokładnie: odczytywania ich z przygotowanej zawczasu listy). Kojarzy się to raczej z działaniami wywiadowcy policyjnego, poborcy podatkowego, egzaminatora, opiekuna społecznego lub - w najlepszym przypadku - osoby ciekawskiej (Mayntz, Holm, Hübner 1985: 149; Neyman-Mascarou 1985: 83) niż ze zwykłą towarzyską pogawędką. Owa sztuczność wywiadu socjologicznego, podkreślana na ogół w odniesieniu do sztywnych ram wywiadu kwestionariuszowego, uwidacznia się również w wywiadach biograficznych, kojarzonych z socjologią humanistyczną, interpretatywną. Tu udzielane przez respondenta odpowiedzi nie są notowane w kwestionariuszu, lecz nagrywane na dyktafon. Fakt nagrywania i wskazana zasadnicza niesymetryczność relacji badacz-respondent (a przede wszystkim, milczenie jednego z „rozmówców”) sprawiają, że założenie o naturalności sytuacji narracyjnej również wydaje się wątpliwe. Słowa E. Neyman-Mascarou, iż „sytuacja społeczna ankiety kreowana przez metodologiczne wymogi uderza sztucznością" (1985: 82), powinny być odnoszone również do narracyjnych wywiadów biograficznych.

Wątpliwości budzi także założenie o „naturalności” i łatwości konstruowania biograficznych narracji. Czy rzeczywiście każdy człowiek jest w stanie stworzyć i zaprezentować opowieść o swoim życiu? Czy faktycznie zdolność taka pozostaje przymiotem każdej jednostki (bez względu na poziom intelektualno-emocjonalnego rozwoju), w odniesieniu do wszystkich zdarzeń życiowych (także tych trudnych, nie w pełni zrozumiałych, wypieranych, przyczyniających się do dysonansu poznawczego)? Sensowna wydaje się odpowiedź przecząca na te pytania. Co więcej, można za M. Prawdą, postawić pytanie, ,,czy my dziś jeszcze w ogóle »opowiadamy«?” (1989: 95). Gdy jednak autor podejmował tę kwestię blisko ćwierć wieku temu, w szkołach uczono pisać 
„życiorysy”, nie zaś tabelaryczne w formie „CV”. Można powiedzieć, że wówczas opisywano własne osiągnięcia (zamiast je wymieniać); pisano wypracowania zamiast wypełniania testów, a telegramy nigdy nie stały się tak popularne jak współczesne SMS-y. Ta „kulturowa zmiana” czyni dziś wywiady biograficzne (czy w ogóle wywiady swobodne) jeszcze trudniejszymi dla badanych. Konstruowanie opowieści nie wydaje się dziś naturalnie łatwe, oczywiste.

Kolejne, przedostatnie założenie wywiadów biograficznych, których tematyka jest dla respondenta trudna lub bolesna, odnosi się do skuteczności zabiegów mających na celu „normalizację” sytuacji po zakończeniu zasadniczej części wywiadu. Cele i formy tych działań odpowiadają stosowanej w psychologii technice tzw. debriefingu. Chodzi tu więc o swobodną rozmowę o samym badaniu i jego przedmiocie, redukcję napięcia, zmianę stanu emocjonalnego na bardziej korzystny i możliwie zbliżony do stanu sprzed badania (Babbie 2004: 521). Czy takie zabiegi są skuteczne? Należy tu powtórzyć, że tematyka wielu wywiadów biograficznych dotyczy doświadczeń trudnych, bolesnych, wstydliwych, częstokroć rugowanych z pamięci, ,usilnie zapominanych”, na co wskazują przywołane wyżej cytaty z wywiadów wykonanych przez B. Engelking. Czy zatem przywołanie owych wypieranych wspomnień w samym wywiadzie może być następnie skutecznie zniwelowane przez zabieg debriefingu? Innymi słowy, czy można skłonić respondenta, aby przypomniał (niejako powtórnie ,przepracował”) sobie określone traumatyczne doświadczenia z przeszłości, a następnie skłonić go, aby ponownie je „zapomniał”, schował do swoistego kufra niepamięci i nie wracał już do niego, tak jak wcześniej doń nie zaglądał? Sensowność takiego zabiegu wydaje się wysoce dyskusyjna... Jeszcze raz należy tu podkreślić, że założenie o skuteczności „,normalizacji”/debriefingu - tak jak pozostałe założenia metody - jest wolne od rygoru weryfikacji. Respondenci nie są już więcej odwiedzani przez badacza lub jego współpracowników i nie jest możliwe stwierdzenie skuteczności zabiegów „normalizacyjnych”. Teza o efektywności tych starań jest więc co najwyżej równie prawdopodobna jak teza o ich zasadniczej nieefektywności.

Ostatnie z założeń odnosi się do psychoterapeutycznych kompetencji socjologa oraz psychoterapeutycznych walorów samych wywiadów biograficznych. Badacze zaznaczają nierzadko, że wykonane przez nich wywiady pozwoliły respondentom na przeżycie swoistego oczyszczenia (katharsis), pozbycie się bagażu traumatycznych doświadczeń, spojrzenie na swoją biografię jako całość czy proces i podjęcie próby nadania jej spójności oraz sensu. Należy jednak podkreślić, że - nawet jeśli takie dobroczynne skutki wywiadów byłyby faktycznie obserwowalne - badacz występuje tu jako terapeuta w sposób samozwańczy. Przez swojego respondenta-pacjenta nie został poproszony o wsparcie, jakiego 
samorzutnie udziela. Aktywność badacza należy więc, w jej quasi-terapeutycznych aspektach, uznać za całkowicie amatorską, a co więcej - narzuconą jej odbiorcy. Analogiczne działania w przypadku medycyny somatycznej (leczenie przez nieprofesjonalistę, bez prośby i zgody pacjenta) byłyby uznane za karygodne. Nawet jeśli socjolog nie jest ,idealnym nie profesjonalistą”, gdyż posiada kompetencje $\mathrm{z}$ zakresu nauk pokrewnych wobec psychologii, to nadal nie jest psychologiem (czy psychoterapeutą), nie posiada stosownych uprawnień, a odbiorca ewentualnie dobroczynnych efektów jego zabiegów uzyskuje je w oparciu o swoją zgodę „na coś innego”.

\section{Zamiast podsumowania: propozycje rekomendacji}

Powyżej wskazane zostały określone problemy etyczne, wiążące się z realizacją wywiadów biograficznych. Należy podkreślić, że wiele z tych problemów uwidacznia się tylko w niektórych przypadkach; chodzi tu zwłaszcza o badania dotyczące kwestii szczególnie bolesnych dla respondentów. Autorzy niniejszego artykułu chcieliby zaproponować kilka rekomendacji, wskazujących na możliwe sposoby minimalizacji ryzyka krzywdy, jaka może stać się udziałem uczestników wywiadów biograficznych.

Po pierwsze, możliwe jest powoływanie na wydziałach uczelni (lub w instytutach) komisji etycznych, opiniujących projekty badawcze przed ich wdrożeniem. To rozwiązanie jest dobrze znane w naukach medycznych ${ }^{3}$. W przypadku socjologii takie rozwiązanie wydaje się mniej oczywiste. Niemniej, jako przykład dobrej praktyki, na gruncie socjologii polskiej, można wskazać Komisję ds. Etyki Badań, powołaną w Instytucie Socjologii Uniwersytetu Warszawskiego. Zgodnie z jej zasadami działania, „Komisja rozpatruje wnioski o stwierdzenie zgodności badań prowadzonych w Instytucie Socjologii ze standardami etycznymi badań społecznych. Wnioski, wraz z dokumentacją mogą składać kierownicy projektów badawczych oraz Dyrekcja Instytutu Socjologii”. Analogiczne rozwiązania są często spotykane w krajach zachodnich; wskazać tu można m.in. następujące przykłady: University of York (Economics, Law, Management, Politics and Sociology Ethics Committee), University of Nottingham (The Nottingham School of Sociology and Social Policy Research Ethics Committee), Queen's University Belfast (School Research Ethics Committee), Wesleyan University (Sociology Ethics Committee), University of Sheffield (Department of Sociological Studies - Department's Research Ethics Committee), University of Manitoba (Psychology/

\footnotetext{
${ }^{3}$ Przykładowo, przy Uniwersytecie Medycznym w Łodzi działa Komisja Bioetyki ds. Badań na Ludziach oraz Senacka Komisja ds. Badań na Zwierzętach, a także Lokalna Komisja ds. Doświadczeń na Zwierzętach.
} 
/Sociology Research Ethics Board), National University of Singapore (Sociology Department Ethics Review Committee). Podstawową zasadą działania komisji jest opiniowanie każdego projektu badawczego. Komisja jest władna zaopiniować projekt negatywnie (i wskazać sposoby jego poprawy), co blokuje jego implementację.

Po drugie, możliwe jest wdrożenie do praktyki realizacji wywiadów biograficznych $\mathrm{w}$ ich narracyjnej formule zasady prowadzenia wywiadów trudnych w towarzystwie wykwalifikowanego psychologa lub psychoterapeuty. Dzięki temu narratorzy w wywiadach dotyczących traumatycznych doświadczeń biograficznych mogliby otrzymywać fachowe wsparcie. Takie samo wsparcie mogłoby być zresztą oferowane samym badaczom, dla których - o czym była mowa wyżej - realizacja wywiadów również może stanowić poważne obciążenie psychiczne. Psycholog lub psychoterapeuta mógłby zagwarantować odpowiednie przeprowadzenie fazy „normalizacji”; mógłby również wskazywać, w których momentach wywiad należy przerwać lub jakie pytania mogą być dla respondenta zbyt trudne (czy wręcz groźne).

Po trzecie, badacze mogą - jeśli jest to możliwe - rezygnować $\mathrm{z}$ realizacji wywiadów biograficznych na rzecz innych technik badawczych. Wydaje się, że odwołanie do wywiadów biograficznych - o których wiadomo, ze względu na tematykę, że będą dla respondentów trudne i bolesne - powinno następować jedynie w przypadku faktycznej niemożności pozyskania porównywalnego materiału empirycznego innymi sposobami. Do grona technik zastępczych zaliczyć należy przede wszystkim analizę danych zastanych, niewywołanych przez badacza. Chodzi tu o wywiady udzielane dziennikarzom, reportaże, fotografie, notatki sporządzane na bieżąco, samorzutnie pisane (i ewentualnie publikowane) pamiętniki i wspomnienia itd. W przypadku wszystkich tych technik zastępczych, z socjologa zdejmowana jest odpowiedzialność bolesnego ,wywoływania cudzych wspomnień" dla własnych celów. Badacz - odwołując się do technik niereaktywnych - korzystałby jedynie z tego materiału, jakiego dostarczają mu bohaterzy interesujących go historii, którzy sami z siebie mają potrzebę ich opowiedzenia.

Trzy wskazane wyżej rozwiązania powinny być traktowane jako uzupełniające się. W optymalnym scenariuszu, wywiady biograficzne realizowane byłyby wyłącznie w takich przypadkach, w których inne sposoby pozyskania porównywalnych danych byłyby nieskuteczne. Nieskuteczność tę powinna stwierdzić komisja etyczna (nie zaś wyłącznie sam badacz, jak dzieje się obecnie), zaś wywiad powinien być prowadzony z udziałem wykwalifikowanego psychologa/ psychoterapeuty, zapewniającego odpowiednie wsparcie obydwu uczestnikom tej specyficznej ,rozmowy”. Rozwiązaniem alternatywnym wobec trzech powyższych rekomendacji jest negowanie i ignorowanie problemu, w imię źle pojętej swobody badań naukowych oraz absolutyzowanej wartości naukowej wiedzy. 


\section{Bibliografia}

Babbie E. (2004), Badania spoteczne w praktyce, Wydawnictwo Naukowe PWN, Warszawa.

Bednarz-Łuczewska P., Łuczewski M. (2012), Podejście biograficzne, [w:] D. Jemielniak (red.), Badania jakościowe. Metody i narzędzia, Wydawnictwo Naukowe PWN, Warszawa.

Cialdini R. (2003), Wywieranie wptywu na ludzi: teoria i praktyka, Gdańskie Wydawnictwo Psychologiczne, Gdańsk.

Czyżewski M., Piotrowski A., Rokuszewska-Pawełek A. (red.) (1998), Biografia a tożsamość narodowa, Wydawnictwo UŁ, Łódź.

Engelking B. (2001), Zagłada i pamięć. Doświadczenie Holocaustu i jego konsekwencje opisane na podstawie relacji autobiograficznych, IFiS PAN, Warszawa.

Golczyńska-Grondas A., Grondas M. (2013), Biographical research and treatment. Some remarks on therapeutic aspects of sociological biographical interviews, [w:] K. Kaźmierska (red.), Metoda biograficzna w naukach społecznych, „Przegląd Socjologii Jakościowej”, t. IX.

Grzeszkiewicz-Radulska K. (2001), Jednostki niedostępne w sondażach CBOS, [w:] P. Daniłowicz, Z. Gostkowski (red.), Sondaże opinii społecznej: samowiedza wspótczesnych spoteczeństw. Analizy i próby technik badawczych $w$ socjologii, t. X, IFiS PAN, Warszawa.

Kaźmierska K. (1996a), Konstruowanie narracji o doświadczeniu wojennej biografii. Na przykładzie analizy narracji kresowych, [w:] M. Czyżewski, A. Piotrowski, A. Rokuszewska-Pawełek (red.), Biografia a tożsamość narodowa, Wydawnictwo UŁ, Łódź.

Kaźmierska K. (1996b), Wywiad narracyjny - technika i pojęcia analityczne, [w:] M. Czyżewski, A. Piotrowski, A. Rokuszewska-Pawełek (red.), Biografia a tożsamość narodowa, Wydawnictwo UŁ, Łódź.

Kaźmierska K. (1999), Doświadczenia wojenne Polaków a kształtowanie tożsamości etnicznej, IFiS PAN, Warszawa.

Kaźmierska K. (2004a) Ethical aspects of biographical interviewing and analysis, [w:] P. Chamberlayne, J. Bornat, U. Apitzsch (eds), Biographical Methods and Professional Practice. An international perspective, The Policy Press University of Bristol, Bristol.

Kaźmierska K. (2004b), Wywiad narracyjny jako jedna z metod $w$ badaniach biograficznych, „Przegląd Socjologiczny”, nr LIII.

Kaźmierska K. (2008), Biografia i pamięć. Na przyktadzie pokoleniowego doświadczenia ocalonych z zagłady, Nomos, Kraków.

Kodeks etyki socjologa uchwalony przez Walne Zgromadzenie Delegatów Polskiego Towarzystwa Socjologicznego dnia 25 III 2012 r., http://www.pts.org.pl/public/upload/kodeks.pdf.

Kubiak A. (2007), Destrukcja procesu akulturacji badań społecznych w Polsce, „Przegląd Socjologiczny", nr LVI. 
Kubiak A. Przybyłowska I., Rostocki W.A. (2001), Badania sondażowe a system demokratyczny niepokoje socjologów, [w:] A. Miszalska, K. Kowalewicz (red.), Niepokojąca wspótczesność, Instytut Socjologii Uniwersytetu Łódzkiego, Łódź.

Lutyńska K. (1984), Wywiad kwestionariuszowy. Przygotowanie i sprawdzanie narzędzia badawczego, Ossolineum, Wrocław.

Lutyński J. (1990), Nauka i polskie problemy. Komentarz socjologa, PIW, Warszawa.

Mayntz R., Holm K., Hübner P. (1985), Wprowadzenie do metod socjologii empirycznej, PWN, Warszawa.

Melchior M. (2004), Zagłada a tożsamość. Polscy Żydzi ocaleni „na aryjskich papierach”. Analiza doświadczenia biograficznego, IFiS PAN, Warszawa.

Międzynarodowy Kodeks Badań Rynku i Badań Społecznych ICC/ESOMAR; http://www.ofbor. pl/public/File/Miedzynarodowy_Kodeks_Badan_Rynku_i_Badan_Spolecznych.pdf.

Neyman-Mascarou E. (1985), Socjolog i maski, [w:] E. Mokrzycki, M. Ofierska, J. Szacki (red.), O społeczeństwie i teorii społecznej: księga poświęcona pamięci Stanistawa Ossowskiego, PWN, Warszawa.

Prawda M. (1989), Biograficzne odtwarzanie rzeczywistości (O koncepcji badań biograficznych Fritza Schütze), „Studia Socjologiczne”, nr 115.

Przybyłowska I. (1996), Proces akulturacji sondaży opinii publicznej w Polsce, „Przegląd Socjologiczny", nr XLV.

Rokuszewska-Pawełek A. (2002), Chaos i przymus. Trajektorie wojenne Polaków - analiza biograficzna, Wydawnictwo UŁ, Łódź.

Rosenthal G. (2003), The healing effects of storytelling: On the conditions of curative storytelling in the context of research and counseling, „Qualitative Inquiry”, vol. 6.

Staszyńska K.M. (1989), Wiarygodność respondentów w socjologicznych badaniach ankietowych, Ossolineum, Wrocław.

Straś-Romanowska M. (2010), Psychologia wobec matych i wielkich narracji, [w:] M. Straś-Romanowska, B. Bartosz, M. Żurko (red.), Psychologia matych $i$ wielkich narracji, ENETEIA, Wydawnictwo Psychologii i Kultury, Warszawa.

Sułek A. (1990), W terenie, $w$ archiwum $i w$ laboratorium. Studia nad warsztatem socjologa, Instytut Socjologii Uniwersytetu Warszawskiego, Warszawa.

Sułek A. (2011), Obrazy z życia socjologii w Polsce, Oficyna Naukowa, Warszawa.

Tokarska U. (2001), Narracja autobiograficzna w terapii i promocji zdrowia, [w:] J. Trzebiński (red.), Narracja jako sposób rozumienia świata, Gdańskie Wydawnictwo Psychologiczne, Sopot.

Tokarska U. (2010), Stawać się Panem Własnego Oblicza. O możliwościach intencjonalnych oddziatywań narracyjnych w biegu życia ludzkiego, [w:] M. Straś-Romanowska, B. Bartosz, M. Żurko (red.), Psychologia matych $i$ wielkich narracji, ENETEIA, Wydawnictwo Psychologii i Kultury, Warszawa. 
Udziat w przychodach ze względu na techniki badawcze. Suplement do badań marketingowych rocznika Polskiego Towarzystwa Badaczy Rynku i Opinii, edycja XVII 2012/13, http://www. ptbrio.pl/index.php?option=com_content $\&$ view=section\&layout=blog\&id=6\&Itemid=6.

Włodarek J., Ziółkowski M. (1990), Teoretyczny i empiryczny status metody biograficznej we wspótczesnej socjologii, [w:] J. Włodarek, M. Ziółkowski (red.), Metoda biograficzna w socjologii, Wydawnictwo Naukowe PWN, Warszawa.

Wylęgała A. (2013), Spoteczna pamięć przesiedlenia: studium porównawcze na przyktadzie dwóch powojennych społeczności lokalnych Polski i Ukrainy, „Studia Socjologiczne”, nr 209. 